\title{
1. Introduction to International Justice in the United Nations General Assembly
}

\section{INTRODUCTION TO THE RESEARCH}

The rise of 'international justice', a field concerned with accountability for atrocity crimes, has led to much reflection on the role of international institutions in addressing impunity gaps. ${ }^{1}$ This literature covers not only international courts tasked with applying the laws of individual criminal responsibility, but other courts - the International Court of Justice (ICJ) and regional human rights mechanisms - in judging State responsibility in atrocity situations. ${ }^{2}$ Similarly, there have been studies on the impact of political institutions in advancing accountability, particularly the United Nations (UN) Security Council. ${ }^{3}$ By

\footnotetext{
1 Eg Naomi Roht-Arriaza, 'Institutions of International Justice' (1999) 52(2) J Intl Aff 473, 476; Steven Ratner and Jason Abrams, Accountability for Human Rights Atrocities in International Law (OUP 1997); Jack Snyder and Leslie Vinjamuri, 'Trials and Errors: Principle and Pragmatism in Strategies of International Justice' (2004) 28(3) Intl Security 5, 5; UNCHR, 'Updated Set of principles for the protection and promotion of human rights through action to combat impunity' (8 February 2005) UN Doc E/CN.4/2005/102/Add.1, 5 (Members undertook to take 'joint and separate action' to respect human rights).

2 Eg Milena Sterio and Michael Scharf (eds), The Legacy of Ad Hoc Tribunals in International Criminal Law (CUP 2019); Cenap Çakmak, A Brief History of International Criminal Law and International Criminal Court: Historical Evolution of International Criminal Law (Palgrave 2017); Charles Jalloh, The Sierra Leone Special Court and its Legacy: The impact for Africa and International Criminal Law (CUP 2014); Claus Kreß, 'The International Court of Justice and the Elements of the Crime of Genocide' (2007) 18(4) EJIL 619; Judith Gardam, 'The Contribution of the International Court of Justice to International Humanitarian Law' (2001) 14(2) LJIL 349.
}

See eg Vincent-Joël Proulx, 'A Postmortem for International Criminal Law? Terrorism, Law and Politics, and the Reaffirmation of State Sovereignty' (2020) 11 Harvard Nat Sec J 151; Jennifer Trahan, 'Revisiting the Role of the Security Council Concerning the International Criminal Court's Crime of Aggression' (2019) 17(3) JICJ 471; David Forsythe, 'The UN Security Council and Response to Atrocities: International Criminal Law and the P-5' (2012) 34 HRQ 840; Marco Roscini, 'The United Nations Security Council and the Enforcement of International Humanitarian 
contrast, there has been little attempt to comprehensively identify, classify and evaluate the contribution of the UN General Assembly (Assembly) to international justice. ${ }^{4}$ The Assembly is a principal organ of the UN and its most representative, comprising the entire membership. ${ }^{5}$ It provides a multilateral forum for States to articulate priorities, mobilise opinion and express disapprobation. ${ }^{6}$ Yet, beyond this political function the Assembly is vested with legal powers to act within the framework of the UN Charter; there has been much debate on the scope of these powers and the effects of its resolutions. ${ }^{7}$

Rooted in this debate, this study examines the Assembly's contribution to international justice. It poses two questions. First, what is the scope of the Assembly's legal powers? 'Power' is evaluated under five functions: (1) 'quasi-legislative'; (2) 'quasi-judicial'; (3) 'empowering'; (4) 'recommendatory'; and (5) 'sanctioning'. Second, having regard to these five functions, to what extent has Assembly practice had an 'effect' in advancing accountability for atrocities? In addressing these questions, this study not only intends to identify the scope of Assembly power but to inspire thinking regarding this organ's potential role in atrocity response.

\section{EXERCISE OF ASSEMBLY FUNCTIONS ON INTERNATIONAL JUSTICE: OVERVIEW}

There has been varying degrees of scholarly analysis on the five functions above, either as part of an abstract legal analysis or thematically in relation to

Law' (2010) 43 Israel LR 330; Marc Weller, 'Undoing the Global Constitution: UN Security Council Action on the International Criminal Court' (2002) 78(4) Intl Aff 693.

4 As to discrete studies: Michael Ramsden, 'The Crime of Genocide in General Assembly Resolutions: Legal Foundations and Effects' (2021) HRL Rev; Rebecca Barber, 'Accountability for Crimes against the Rohingya: Possibilities for the General Assembly where the Security Council Fails' (2019) 17(3) JICJ 557; Alex Whiting, 'An Investigation Mechanism for Syria: The General Assembly Steps into the Breach' (2017) 15(2) JICJ 231; Michael Ramsden and Tom Hamilton, 'Uniting against Impunity: The UN General Assembly as a Catalyst for Action at the ICC' (2017) 66 ICLQ 893; Michael Ramsden, 'Uniting for MH17' (2017) 7(2) Asian J Intl L 337.

5 Being 193 Members as of 2020, plus two non-member observer states (Holy See and Palestine).

6 Inis Claude, 'Collective Legitimization as a Political Function of the United Nations’ (1966) 20(3) Intl Org 367.

7 Eckart Klein and Stefanie Schmahl, 'Ch. IV The General Assembly, Functions and Powers' in Bruno Simma and others (eds), The Charter of the United Nations, vol 1 (OUP 2012); Michael Schmidt, 'UN General Assembly' in Alex Bellamy and Tim Dunner, Oxford Handbook on the Responsibility to Protect (OUP 2016); Nigel White, 'Relationship between the Security Council and General Assembly' in Marc Weller (ed), The Oxford Handbook of the Use of Force in International Law (OUP 2015). 
their application in a particular area. This section considers the most important scholarly contributions on these functions and identifies gaps in this literature in the international justice field.

\section{1 'Quasi-Legislative'}

It is plain that the UN Charter does not provide the Assembly with a 'legislative' competence, in being able to enact law binding States. ${ }^{8}$ Still, the Assembly was vested with a standard-setting function, Article 13 empowering it to 'initiate studies and make recommendations' to encourage 'the progressive development of international law and its codification'. ' It is apparent that Assembly resolutions have contributed towards the development of international law. There is now established institutional lexicon to signal that a 'recommendation', as formally defined, is, in fact, performing a function of identifying existing international law. As Chapter 2 of this volume makes clear, resolutions of this nature are often phrased as 'declarations' or use other language to denote recognition of international law (such as 'affirmation'). The Assembly, for its part, has accepted that the 'development of international law may be reflected' in its 'declarations and resolutions'. ${ }^{10}$ However, asserting that international law is identified in a resolution is one thing. Whether the resolution has an impact on actors applying international law is another.

The notion Assembly resolutions are capable of having 'quasi-legislative' effects, as Richard Falk noted in 1966, represents a middle position between a formal recognition of true legislative status and the formal denial of any law-creating role. ${ }^{11}$ As noted above, a proposal to confer upon the Assembly a power to legislate was rejected by the Charter drafters. Yet, the Assembly's nature, as a forum comprising a near universal membership of States, provides scope for a shared legal position to be articulated. To treat a subset of resolutions as 'quasi-legislative' invites analysis on the extent to which they acquire 'normative status in international life', in supporting the interpretive legal claims of States, courts or other actors. ${ }^{12}$ Falk noted that the formal description of resolutions as 'non-binding' does not reflect their influence; some interna-

\footnotetext{
8 See eg 9 UNCIO Docs 316 (1945) (Philippine delegation proposal to vest legislative power in the Assembly rejected 26-1).

9 Charter of the United Nations (entered into force 24 October 1945) 1 UNTS 16 ('UN Charter'), art 13.

10 ibid. See also UNGA Res 3232 (XXIX) (1974) ('development of international law may be reflected ... by declarations and resolutions ...').

11 Richard Falk, 'On the Quasi-Legislative Competence of the General Assembly' (1966) 60(4) AJIL 782.

12 ibid, 784.
} 
tional courts, even at the time of his writing in 1966, displayed a tendency to use non-binding instruments in the construction of international law. ${ }^{13}$ As to what would make a resolution more or less persuasive from a quasi-legislative perspective, Falk noted a number of contextual factors, including the use of 'declaratory language' together with 'the expectations governing the extent of permissible behaviour, the quality of the consensus, and the degree to which effective power is mobilized to implement the claims posited in a resolution'. ${ }^{14}$ The degree to which resolutions are prescriptively authoritative depends upon the extent to which they 'influence behaviour and gain notoriety in legal circles' and come to be 'incorporated into the developing framework of an evolving system and science of international law'. ${ }^{15}$ Accordingly, limits upon the Assembly's quasi-legislative competence are less a reflection of the absence of a formal competence to legislate as they are a consequence of political constraints arising from a requirement to mobilise community power in support of legislative claims. ${ }^{16}$

There has been some attempt to measure, as Falk envisaged, the extent to which communities have mobilised the legislative claims contained in resolutions. Hurst Hannum thus conducted a comprehensive jurisprudential survey of the varied ways domestic courts have applied the 1948 Universal Declaration of Human Rights (UDHR), noting the instances it has been found to reflect customary international law. ${ }^{17}$ The impact of the 1974 Definition on Aggression has been studied, particularly on Security Council decision-making. ${ }^{18}$ However, there has been no comprehensive attempt to trace the impact of Assembly resolutions in the judicial interpretation of international law concerned with responsibility for atrocities. Given the growing judicial architecture to enforce international justice, including the International Criminal Court (ICC) and ad hoc tribunals, as well as regional human rights mechanisms, this book aims to fill this research gap.

\footnotetext{
ibid, 783.

ibid, 786.

ibid.

ibid, 788.

Hurst Hannum, 'The Status of the Universal Declaration of Human Rights in National and International Law' (1995) 25 Ga J Intl \& Comp L 287; UNGA Res 217 A (III) (1948). See also Krzysztof Skubiszewski, 'Recommendations of the United Nations and Municipal Courts' (1972-1973) (46) BYBIL 353; Egon Schwelb, 'An instance of enforcing the Universal Declaration of Human Rights, action by the Security Council' (1973) 22 ICLQ 161.

18 See eg Nicolaos Strapatsas, 'The Practice of the Security Council Regarding the Concept of Aggression' in Claus Kreß and Stefan Barriga (eds), The Crime of Aggression: A Commentary (CUP 2017); UNGA Res 3314 (XXIX) (1974), annex.
} 
The evidentiary value of Assembly resolutions to the development of international law has been extensively considered, revealing a range of opinions. ${ }^{19}$ Stephen Schwebel doubted that States mean what they say when voting in support of resolutions declaring law. ${ }^{20}$ By contrast, Bin Cheng argued that in areas of international legal vacuums a resolution is able to constitute 'instant custom' in authoritatively explicating the opinio juris of the new custom. ${ }^{21}$ A more moderate position was offered by Samuel Bleicher, who saw merit in resolutions declaring international law, provided there is persistent recitation of the norm in resolutions. ${ }^{22}$ This debate is deserving of fresh consideration in light of the jurisprudential survey conducted in this book and the International Law Commission's (ILC) recent conclusion of a major study into the processes of identifying custom, which includes analysis on the normative weight of resolutions. $^{23}$

\section{2 'Quasi-Judicial'}

Although the UN Charter vests judicial power in the ICJ it is also clear that the Assembly, to effectively discharge its functions, needs to form evaluative judgments on certain facts and disputes. There are numerous Charter provisions involving the Assembly in decision-making which, although limited to internal operational matters, might impact a wider dispute. Whether the Assembly is to accept the credentials of a delegation seeking to represent a Member State might involve an assessment of the merits of this delegation according to a legal standard, especially where there are competing claims (of which, see Chapter 4 of this volume). ${ }^{24}$ Yet, even where the Assembly is confined to its recommendatory function, an evaluative judgment as to an underlying dispute will often be necessary for this function to be meaningfully exercised. Under Chapter IV of the Charter, the Assembly can furnish recommendations to Members of the Security Council for the 'peaceful adjustment of any situation', ${ }^{25}$ or to provide a response to situations that 'endanger international peace and security', ${ }^{26}$ and which it 'deems likely to impair the general

\footnotetext{
19 See Chapter 3 of this volume.

20 Stephen Schwebel, 'The Effect of Resolutions of the UN General Assembly on Customary International Law' (1979) 73 ASIL Proc 301, 308.

21 Bin Cheng, Studies in International Space Law (Clarendon 1998), 139-41.

22 Samuel Bleicher, 'The Legal Significance of Re-Citation of General Assembly Resolutions' (1969) 63 AJIL 444.

23 ILC, 'Draft Conclusions on Identification of Customary International Law, with Commentaries' (2018) UN Doc A/73/10.

24 ibid, arts 4(2), 6 and 17.

25 ibid, art 14.

26 ibid, art 11(3).
} 
welfare or friendly relations among nations, including situations resulting from a violation of the provisions of the present Charter setting forth the Purposes and Principles of the United Nations'. ${ }^{27}$ The exercise of these Charter powers entails what is described here as 'quasi-judicial', in monitoring compliance with law or making evidence-based factual determinations a precursor to the Assembly exercising its decisional or recommendatory competencies. ${ }^{28}$

The Assembly's quasi-judicial function has received scholarly attention over the years. The earliest, most significant contribution was provided by Oscar Schachter in 1964 who, in surveying UN practice in the first two decades, observed trends even though such resolutions were 'few in number' (concerning use of force, decolonisation and racial discrimination).$^{29}$ Indeed, this scholarly contribution pre-dates many developments in quasi-judicial practice, particularly from the 1970s onwards, described in this book. Nonetheless, Schachter queried the basis for this quasi-judicial function that remains pertinent today. Especially problematic was the Assembly, as a political organ, passing judgment on State conduct without observing judicial standards of impartiality; the concern being that the Assembly, as a political organ, produces an environment in which States vote in their self-interest and along partisan lines, which might deprive any determination of the impartial application of a legal standard found in judicial processes. ${ }^{30}$ Nonetheless, Schachter considered that partisanship would not be the sole determinant of a quasi-judicial resolution; Members, acting through a multilateral organ, cannot act solely on the basis of their national interest but are shaped by a common interest that mitigates bias. ${ }^{31}$ Schachter hypothesised that the quasi-judicial resolutions exert meaningful pressure on relevant actors to comply with or implement what was recommended, as evaluations by the Assembly possess a 'degree of authority that generates pressures' towards observance. ${ }^{32} \mathrm{He}$ observed the possibility for quasi-judicial resolutions to contribute towards the development of international law; the application of law to a situation is a 'law-creative act, even though the members of the organ maintain (as they often do) that their

\footnotetext{
27 ibid, art 14.

28 Mara Tignino, 'Quasi-judicial bodies' in Catherine Brölmann and Yannick Radi (eds), Research Handbook on the Theory and Practice of International Lawmaking (Edward Elgar Publishing 2016), 242.

${ }_{29}$ Oscar Schachter, 'The Quasi-Judicial Role of the Security Council and the General Assembly' (1964) 58 AJIL 960, 961; Blaine Sloan, 'The Binding Force of a Recommendation of the General Assembly of the United Nations' (1948) 25 Brit YB Intl L 1, 28.

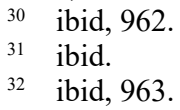


decision is confined to the specific facts and they do not intend to establish a precedent'. ${ }^{33}$

Scholars have continued to evaluate the Assembly's quasi-judicial function. Christian Tomuschat thus analysed the Assembly's role in monitoring compliance with human rights law. ${ }^{34}$ Tomuschat acknowledged that political bodies such as the Assembly have 'great difficulties satisfying the requirement to act in a fair and objective manner', but saw advantage in collective State involvement as carrying 'more weight than assessments by expert bodies'. ${ }^{35}$ While considering Assembly resolutions to be 'no panacea to cure all conceivable ills', Tomuschat noted their 'moral weight' to be considerable; no State 'likes being blamed by the world community for failure to heed generally recognized international standards'. ${ }^{36}$ At the same time, according to Tomuschat, the most intensive forms of disapproval of a State's conduct do not free the Assembly 'from the constraints of its competencies' ${ }^{37}$ Continuing the theme that a determination contained in an Assembly recommendation does not carry legal effects, Marko Öberg surveyed the use of quasi-judicial resolutions in the ICJ's jurisprudence, noting their usefulness in establishing a persuasive narrative of events, but cautioning that the Court with its judicial nature and its careful approach to establishing facts, should not be bound by such determinations' ${ }^{38}$ By contrast, Nigel White observed that resolutions adopted by consensus or large majorities, and based upon international law, are likely to be 'authoritative' legal determinations. ${ }^{39}$ Likewise, Rebecca Barber considered the basis for the Assembly to certify that the legal conditions exist for States, invoking the necessity doctrine, to intervene in another State to provide humanitarian assistance. ${ }^{40}$

This book builds upon the literature by considering the Assembly's quasi-judicial function to secure atrocity accountability. There has been no comprehensive survey on the Assembly's application of international law in atrocity situations, comprising the core international crimes (genocide, war

33 ibid, 964.

34 Christian Tomuschat, Human Rights: Between Idealism and Realism (OUP 2014), 184.

35 ibid.

36 ibid, 198.

37 ibid, 198.

38 Marko Öberg, 'The Legal Effects of Resolutions of the UN Security Council and General Assembly in the Jurisprudence of the ICJ' (2006) 16 EJIL 879, 892.

39 Nigel White, The Law of International Organisations (MUP 2005), 179.

40 Rebecca Barber, 'Does International Law Permit the Provision of Humanitarian Assistance Without Host State Consent? Territorial Integrity, Necessity and the Determinative Function of the General Assembly', in Terry Gill and others (eds), Yearbook of International Humanitarian Law 2020 (TMC Asser Press 2021). 
crimes, crimes against humanity and aggression) and serious human rights violations. It also grapples with two important themes in the existing literature: the propriety of quasi-judicial activity and the observable effects of these resolutions. This book considers these issues in the context of international justice and the impact of quasi-judicial resolutions on the main instituional actors in the field: the ICC, ICJ, the UN ad hoc tribunals, regional human rights mechanisms and the UN's other principal political organ, the Security Council. ${ }^{41}$ Given the important role of courts in enforcing international justice, in imposing individual or State responsibility for atrocities, it is therefore interesting to examine the extent to which Assembly resolutions have been used by courts to support their decisions.

\section{3 'Recommendatory'}

Under a trio of provisions in the UN Charter, the Assembly has powers to make 'recommendations' to Member States and the Security Council. Article 10 grants the Assembly power to discuss matters falling within the Charter or 'relating to the powers or functions of any organs provided for' in the Charter, and to make recommendations on such matters to Members or the Council, or both. ${ }^{42}$ Article 11 elaborates on the Assembly's powers in maintaining international peace and security. Article 11(2) thus provides that the Assembly may discuss 'any question relating to the maintenance of international peace and security' brought to it by a Member or the Council and 'may make recommendations with regard' to such questions. Article 11(3) adds texture to the Assembly's power to furnish recommendations to the Council pertaining 'to situations which are likely to endanger international peace and security'. Finally, Article 14 allows the Assembly to recommend measures 'for the peaceful adjustment of any situation' which it 'deems likely to impair the general welfare or friendly relations among nations, including situations resulting from a violation of the provisions of the present Charter setting forth the Purposes and Principles of the United Nations'.

Whether an Assembly 'recommendation' imposes obligations was famously addressed by Blaine Sloan in $1948 .{ }^{43}$ Sloan rejected the proposition that the ordinary meaning of 'recommendation' means that the Assembly was unable to bind Members. Rather, 'no single conclusion' can be made on the legal nature of 'recommendations', either based on the Charter text or its drafting

${ }^{41}$ Michael Ramsden, “"Uniting for Peace” in the Age of International Justice' (2016) 42 Yale J Intl L 1.

42 See Klein and Schmahl (n 7), 463.

43 Sloan, 'Binding Force' (n 29). 
history. ${ }^{44}$ Aside from the Assembly's ability to take decisions on internal operational matters, Sloan noted that recommendations might come to bind Member States, by way of an institutional customary rule. ${ }^{45}$ Sloan recognised the Assembly's dual role, as a body with its own legal personality under the Charter, but also a congress of individual nations possessing 'inherent powers which need not derive from a specific enumeration in the Charter' ${ }^{46}$ Sloan here recognises the membership's role in developing Assembly powers, by attributing to this body authoritative competencies through institutitonal practice, 'where the intention is to be so bound' ${ }^{47}$ Although the Assembly has used various phrases to convey a legal expectation of compliance with a recommendation (from 'invites' to 'request'), he accepted it as necessary to 'approach the realm of de lege ferenda' to consider the possibilities for an institutional custom to emerge. ${ }^{48}$ Sloan envisaged a role for the Assembly in areas that are lacking sufficient international oversight but where Members have international obligations; 'the protection of human rights falls or will be brought into a sphere of action where binding resolutions may be made' ${ }^{49}$ The Assembly 'may assert the right to enter the legal vacuum and take a binding decision'. ${ }^{50}$

Despite Sloan paving the way for scholarship on the significance of Assembly practice towards a 'binding recommendation', there has been little consideration of this practice. The conventional wisdom is often cited; recommendations are not legally binding. ${ }^{51}$ It might be that this scholarship is merely following the practice, or lack thereof, which has not developed as Sloan anticipated when writing in $1948 .{ }^{52}$ Nonetheless, it is instructive to consider whether practice shows any emerging consensus on binding recommendations

44 ibid, 7 (concerning the Philippines proposal to confer upon the Assembly a legislative competence, the "enacting of legislation is not the only way in which binding decisions are made').

45 ibid, 15,19 . States might also agree to be bound by resolutions by way of special agreement: ibid, 16; Louis Sohn, 'The Second Year of United Nations Legislation' (1948) ABAJ 315.

46 ibid, 22.

47 ibid, 22.

48 ibid, 23.

49 ibid, 24.

50 ibid, 24. See a narrower view in Hans Kelsen, The Law of the United Nations (Stevens 1950), 40, 195-96 (Assembly recommendations on international peace and security are binding; those on economic and social cooperation, including human rights, have 'no legal effect whatsoever').

${ }_{51}$ Blaine Sloan, United Nations General Assembly Resolutions in Our Changing World (Brill 1992), 5 (criticising this misconception).

52 This scholarship has tended to focus on the ICJ's use of Assembly resolutions: Öberg (n 38); DHN Johnson, 'The Effect of Resolutions of the General Assembly of the United Nations' (1955-1956) 32 BYBIL 97. 
in relation to accountability for atrocity crimes. As noted, Sloan anticipated that recommendations become binding in areas where legal vacuums exist. Although the mechanisms to enforce and monitor compliance with international justice have advanced considerably, a major criticism remains that there is a lack of sustained institutional leadership in holding States to their international obligations. ${ }^{53}$ The extent to which the Assembly has stepped into the breach, to call upon Members to meet their obligations to prosecute atrocity crimes, and done so by injecting legal requirements into recommendations, therefore justifies attention.

Aside from debate over binding recommendations, writers have analysed their extra-legal effects. Sloan argued that 'recommendations possess moral force and should, as such, exert great influence'. ${ }^{4}$ This was so because the Assembly 'represents the will of the majority of nations', with this body enjoying 'an advantage because of the opportunity, which is not always available in the sphere of international law, for full publicity and for a recorded vote'. ${ }^{55}$ That recommendations are non-binding does not preclude them from influencing State behaviour, having a 'moral and political motivating force which makes it more effective than many a legal norm'. ${ }^{66}$ DHN Johnson preferred to characterise recommendations as carrying some 'political effect', in that Members who do not observe them 'run the risk of losing the political friendship and understanding of their fellow Members who voted for the resolution' ${ }^{57}$ However, these extra-legal effects have been largely assumed without proof. For instance, Gabriella Lande noted there to be 'little doubt' that Members give 'some attention' to Assembly resolutions given the bargaining that often occurs prior to their adoption. ${ }^{58}$ Similarly, other scholars have pointed generally to the factors that might indicate the degree to which recommendations are capable of producing political effects, looking to the 'quality, quantity and intensity of community support behind them'. ${ }^{59}$ Accordingly, this book will embrace this literature on effects when examining Assembly's recommendations practice on international justice.

53 See in particular the criticisms of Security Council leadership in $\mathrm{n} 3$ above.

54 Sloan, 'Binding Force' (n 29), 31.

55 ibid.

56 Alf Ross, Constitution of the United Nations: Analysis of Structure and Functions (Einehart 1950), 60-61.

57 Johnson (n 52), 121; Clyde Eagleton, International Government (Ronald Press 1948), 322 ('desperate parliamentary battles may be fought to avoid unfavourable conclusions').

${ }_{58}$ See eg Gabriella Lande, 'The Effect of the Resolutions of the United Nations General Assembly' (1966) 19(1) World Politics 83, 100.

59 Daniel Cheever and Field Haviland, Organizing for Peace: International Organization in World Affairs (Hughton Mifflin 1954), 89. 
Aside from the Assembly being able to act quasi-judicially, it can empower judicial or subsidiary entities for an adjudicatory or fact-finding purpose. This empowering function is enshrined in the UN Charter and, as this book explores, in Assembly practice. Article 22 empowers the Assembly to 'establish such subsidiary organs as it deems necessary for the performance of its functions'. This provision has been interpreted broadly where it has arisen in cases before the ICJ, it being left to the 'Assembly to appreciate the need for any particular organ', with it being contrary to the Charter 'to place a restrictive interpretation' on this power. ${ }^{60}$ In addition to being able to establish subsidiary organs, Article 96(1) empowers the Assembly to request an advisory opinion from the ICJ on 'any legal question', supporting the possibility of Assembly-ICJ dialogue on atrocity situations.

The extent to which the Assembly has used, and is capable of using, these provisions to advance accountability for atrocities has been considered in the scholarly literature. This has broadly tracked and critiqued Assembly 'empowering' practice but also involved imaginative proposals for how this power might be extended and applied in the future. The Assembly's creation of the International, Impartial and Independent Mechanism for Syria ('IIIM-Syria') in 2016 led numerous scholars to justify this mechanism in light of the opposition to it by a minority of States. ${ }^{61}$ The Assembly's power to request advisory opinions has also been analysed, from the perspective of legal limits and political propriety. ${ }^{62}$ Scholars have argued for use of the advisory mechanism in atrocity situations to clarify the Security Council's Charter responsibilities

60 See Chapter 6 of this volume; Application for Review of Judgment No. 158 of the United Nations Administrative Tribunal (Advisory Opinion) [1973] ICJ Rep 66, 172.

${ }_{61}$ Whiting (n 4); Christian Wenaweser and James Cockayne, 'Justice for Syria? The International, Impartial and Independent Mechanism and the Emergence of the UN General Assembly in the Realm of International Criminal Justice' (2017) 15(2) JICJ 211; Beth van Schaack, 'The General Assembly and Accountability for International Crimes' (Just Security, 27 February 2017) [www.justsecurity.org/38145/ general-assembly-accountability-international-crimes/]. See also Andrew Hudson and Alexandra Taylor, 'A New Model for International Criminal Justice Mechanisms' (2010) 8 JICJ 53.

62 Martin Lailach, 'The General Assembly's Request for an Advisory Opinion from the International Court of Justice on the Legality of the Threat or Use of Nuclear Weapons' (1995) 8 LJIL 401; Michla Pomerance, 'The ICJ's Advisory Jurisdiction and the Crumbling Wall between the Political and the Judicial' (2005) 99(1) AJIL 26; Andrea Bianchi, 'Dismantling the Wall: The ICJ's Advisory Opinion and Its Likely Impact on International Law' (2004) 47 GYIL 343; Karin Oellers-Frahm, 'Law-making through Advisory Opinions?' (2011) 12(5) German LJ 1033. 
or to offer judicial scrutiny of alleged serious violations of international law. ${ }^{63}$ Finally, there has been imaginative proposals for the Assembly to establish ad hoc criminal tribunals where there are no other ways to secure accountability. ${ }^{64}$ Rebecca Barber presented this accountability solution for crimes against the Rohingya ${ }^{65}$ According to Barber, the Assembly is able to establish an ad hoc tribunal based upon its established practice in creating subsidiary mechanisms in advancing the Charter purpose of maintaining international peace and security. ${ }^{66}$

While these are important perspectives on the Assembly's capacity to empower investigations into atrocity situations, there is a need for further analysis on these powers. It is now relatively uncontroversial to conclude that the Assembly can create commissions of inquiry (COI). However, the recent innovation of subsidiary organs being vested with 'quasi-prosecutorial' powers, in preparing cases to support the investigation and prosecution of individual suspects, deserves more analysis. Similarly, while it appears to be conventional wisdom that there is no duty to cooperate with Assembly-established COIs, this proposition is worth closer scrutiny in light of Assembly practice, the text of resolutions and the views of Member States. This might reveal less uniformity on this proposition than originally thought and the possibility for a cooperation duty to emerge. Concerning the Assembly's use of its power to request an advisory opinion, existing scholarship has tended to focus on the propriety of individual requests; it is instructive to consider the potential for this mechanism to address gaps in the judicial accountability of atrocity crimes. Finally, beyond Barber's focus on established practice as a foundation to create an ad hoc tribunal, there are other potential legal bases that warrant closer attention. One possibility was alluded to in the COI report concerning alleged crimes against humanity in the Democratic People's Republic of Korea (DPRK). ${ }^{67}$ This report alluded to the possibility that the Assembly could establish an ad hoc tribunal, using Uniting for Peace, or the 'combined sovereign

63 Jennifer Trahan, Existing Legal Limits to Veto Powers in the Face of Atrocity Crimes (CUP 2020), 254-55; James Goldston, 'We Need an ICJ Ruling on Syria' (Open Democracy, 27 June 2015) [www.opendemocracy.net/en/north-africa-west-asia/ we-need-icj-ruling-on-syria/] (discussing the possibility of an Assembly request for an ICJ advisory opinion on Syria).

${ }_{64}$ The Assembly's potential to exercise an ICC referral power has also been analysed: Ramsden and Hamilton (n 4).

${ }_{65}$ Barber, 'Accountability' (n 4). See also Ramsden, 'Uniting for MH17' (n 4).

66 ibid.

67 UNHRC, 'Report of the detailed findings of the commission of inquiry on human rights in the Democratic People's Republic of Korea' (7 February 2014) UN Doc A/ HRC/25/CRP.1. 
powers' of Members States to assert universal jurisdiction. ${ }^{68}$ These claims are considered in Chapter 6 of this volume.

\section{5 'Sanctioning'}

Although the UN Charter envisages a role for the Security Council in sanctioning States for their deviant conduct, it is also apparent that the Assembly is able to perform a limited sanctioning function. To be sure, Article 41 of the Charter provides the most direct reference to a sanctioning power, in empowering the Council to decide upon appropriate non-forceful measures Member States ought to take to address threats to international peace and security, including the 'complete or partial interruption of economic relations and of rail, sea, air, postal, telegraphic, radio, and other means of communication, and the severance of diplomatic relations' ${ }^{69}$ Yet, the Assembly might also sanction a Member in a limited sense of contributing towards a decision that deprives such Member of some or all of its rights of membership. Article 5 of the Charter provides that, where the Council has taken 'preventive or enforcement action' against a Member, the Assembly might, 'upon the recommendation of the Security Council' suspend that State 'from the rights and privileges of membership'. Furthermore, Article 6 provides that, 'upon the recommendation of the Security Council', the Assembly can expel a Member that has 'persistently violated' the principles of the Charter. Although the Assembly is unable to exercise these powers independent of a Council recommendation, it might autonomously make a decision concerning the credentials of those delegates seeking to represent Members.

The extent to which the Assembly is able to sanction Members has attracted some attention in the scholarly literature. This scholarship falls into three main clusters. The first evaluates Assembly practice in depriving an offending State of its UN membership rights, be that under Article 6 or in considering the credentials of a government that purports to represent a State in the Assembly. ${ }^{70}$ Another cluster of scholarship has analysed the possibility for the Assembly

\footnotetext{
68 ibid, [1201].
}

69 However, art 41 is not solely confined to sanctioning violations of international law but maintaining international peace and security. For a detailed analysis: Nico Krisch, 'Ch.VII Action with Respect to Threats to the Peace, Breaches of the Peace, and Acts of Aggression, Article 41' in Bruno Simma and others (eds), The Charter of the United Nations: A Commentary, vol II (3rd edn, OUP 2012), 1310.

70 See eg Farrokh Jhabvala, 'The Credentials Approach to Representation Questions in the U.N. General Assembly' (1977) 7 Cal W Intl LJ 615; Gerhard Erasmus, 'Rejection of Credentials: A Proper Exercise of General Assembly Powers or Suspension by Stealth?' (1981) 7 South African J Intl L 40; Malvina Halberstam, 'Excluding Israel from the General Assembly by a Rejection of its Credentials' (1984) 
to contribute towards the lawful imposition of economic sanctions against States that have violated their international obligations. ${ }^{71}$ Stefan Talmon considered the possible 'authorising' function of Assembly resolutions and their interaction with numerous doctrines of State responsibility, including countermeasures and 'fundamental change of circumstances' ${ }^{72}$ Finally, scholars have considered the use of Uniting for Peace to confer upon the Assembly analogous enforcement powers to those of the Security Council, including to legally authorise sanctions. ${ }^{73}$ This has also considered the constitutionality of this mechanism, in purporting to confer upon the Assembly powers not obviously contemplated in the Charter (including Article 41). ${ }^{74}$ Given that use of Uniting for Peace has been in decline, recent scholarship has questioned its continued utility. ${ }^{75}$

This book complements the existing literature by analysing the Assembly's potential involvement in coordinating sanctions. Much of the literature on the Assembly's sanctioning function has not been specifically focused on how it might be used as an instrument to advance accountability for atrocities. For example, Uniting for Peace scholarship is preoccupied with the Assembly's power to authorise the use of force, rather than how this mechanism might

78 AJIL 179, 186-87; Alison Duxbury, The Participation of States in International Organisations: The Role of Human Rights and Democracy (CUP 2011).

${ }_{71}$ John Halderman, 'Some Legal Aspects of Sanctions in the Rhodesian Case' (1968) 17(3) ICLQ 672.

72 Stefan Talmon, 'The Legalizing and Legitimizing Function of UN General Assembly Resolutions' (2014) 108 AJIL Unbound 123.

73 Andrew Carswell, 'Unblocking the UN Security Council: The Uniting for Peace Resolution' (2013) 18(3) JCSL 453; Rebecca Barber, 'Uniting for Peace not Aggression: Responding to Chemical Weapons in Syria Without Breaking the Law' (2019) 24(1) JCSL 71; Christian Tomuschat, 'Uniting for Peace' (2008) UN Audiovisual Lib Intl L 3 [http://legal.un.org/avl/pdf/ha/ufp/ufp_e.pdf].

74 Juraj Andrassy, 'Uniting for Peace' (1956) 50 AJIL 563, 564; Hans Kelsen, 'Is the Acheson Plan Constitutional?' (1950) 3(4) Western Political Q 512, 516; Leland Goodrich, 'Expanding Role of the General Assembly: The Maintenance of International Peace and Security' (1951) 29 Intl Conciliation 231; LH Woolsey, 'The “Uniting for Peace” Resolution of the United Nations' (1951) 45(1) AJIL 129, 134.

75 Larry Johnson 'Uniting for Peace: Does it Still Serve any Useful Purpose?' (2014) 108 AJIL Unbound 106; Jean Krasno and Mitushi Das, 'The Uniting for Peace Resolution and Other Ways of Circumventing the Authority of the Security Council' in Bruce Cronin and Ian Hurd (eds), The UN Security Council and the Politics of International Authority (Routledge 2008); Harry Reicher, 'The Uniting for Peace Resolution on the Thirtieth Anniversary of its Passage' (1981) 10 Colum J Transnatl L 1, 36-37; Henry Richardson, 'Comment on Larry Johnson, Uniting for Peace' (2014) 108 AJIL Unbound 135; Ramsden, 'Age of International Justice' (n 41). 
support accountability efforts. ${ }^{76}$ It is therefore instructive to provide a comprehensive and holistic analysis on the potential for Assembly resolutions to have legal effects that augment sanctions against those responsible for atrocities.

As the above review shows, there is a need for comprehensive analysis on the Assembly's contribution to international justice. This book has three goals. Firstly, it seeks to identify the scope of the Assembly's legal powers, according to five functions (i.e., quasi-legislative, quasi-judicial, empowering, recommendatory, sanctioning). A full explication of these powers also raises the possibility for the Assembly to be used by States and other actors to advance accountability in an atrocity situation and, hopefully, to stimulate creative thinking on how the UN plenary body can be used to address impunity gaps. Secondly, the book also seeks to provide a comprehensive survey of Assembly practice on international justice, which includes the adoption of resolutions and decisions, as well as creation of subsidiary organs. By outlining this practice, the book aims to highlight to the reader areas where the Assembly has been active and to, conversely, identify areas where gaps or inconsistencies exist in responding to atrocity crimes. Thirdly, the book aims to advance scholarly understanding on the 'effects' of Assembly resolutions, broadly conceived, using international justice as a case study in which to appreciate these effects.

In this respect, 'effects' are measured in different ways in this book. The quasi-legislative effects of resolutions focus on their contribution towards the judicial development of relevant international law. Furthermore, as developed in Chapter 4 of this volume, a derivative of quasi-judicial resolutions, in applying norms in a country situation, is enabling Member States to crystallise a legal understanding that contributes towards the development of international law: a quasi-judicial resolution can therefore have quasi-legislative effects. Still, measuring the political impact of resolutions on the behaviour of Members and the Security Council is more difficult. The most direct form

76 Carswell (n 73); Dominik Zaum, 'The Security Council, The General Assembly, And War: The Uniting for Peace Resolution' in Vaughan Lowe and others (eds), United Nations Security Council and War: The Evolution of Thought and Practice Since 1945 (OUP 2008); Coman Kenny, 'Responsibility to Recommend: The Role of the UN General Assembly in the Maintenance of International Peace and Security' (2016) 3(1) J Use of Force Intl L 3; Barber, 'Uniting for Peace not Aggression' (n 73); Graham Melling and Anne Dennett, 'The Security Council Veto and Syria: Responding to Mass Atrocities through the "Uniting for Peace" Resolution' (2018) 57(3-4) IJIL 285; Michael Ramsden, 'Uniting for Peace and Humanitarian Intervention: The Authorising Function of the UN General Assembly’ (2016) 25(2) Wash Intl LJ 267. 
is that either of these subjects implement the recommendation; however, establishing causality is challenging (these actors are unlikely to attribute decisions they make to anything other than their own considered judgment). Equally problematic is that attempts to secure accountability for atrocities often fail despite multilateral efforts. ${ }^{77}$ Nonetheless, a recommendation might produce certain institutional effects which are worthy of analysis, in leading to a stronger response from the Assembly, in mobilising shame against a deviant State, or in calling for Security Council action. It is instructive therefore to consider whether defiance of recommendations produced any further effects that contributed towards the crystallisation of a UN position, in shaping an international public attitude towards a situation. Finally, there are effects that remain, at this point, largely hypothetical, as with Assembly resolutions that purport to authorise Members to take action otherwise inconsistent with international law (see Chapter 7 of this volume).

In evaluating these effects, it is acknowledged that a medley of factors will affect the degree to which the Assembly is capable of having impact. The factors noted by Richard Falk in the previous section - including the nature and scale of support for a resolution - are amongst those relevant to how a resolution is received and used in international life. But it must also be appreciated that there are other political mechanisms in international justice. Within the UN, the Security Council is able to take enforcement action to advance accountability, best illustrated by its power to refer situations to the ICC Prosecutor. ${ }^{78}$ The UN Human Rights Council (UNHRC) has also assumed the leading position for creating COIs which have produced impact, including on Security Council decision-making. ${ }^{79}$ Outside of the UN, the ICC Assembly of States Parties (ICC-ASP) has plenary oversight over the ICC, adopting amendments to the ICC Statute and mobilising shame against deviant States Parties.$^{80}$ Regionally, there are various political initiatives to address impunity gaps undertaken by the European Union (EU) and African Union (AU) ${ }^{81}$ Appreciating Assembly impact also has to take into account the contributions of these other actors and inter-institutional habits of cooperation that have

77 UNGA, Fifty-fourth session, 80th plenary meeting (15 December 1999) UN Doc A/54/PV.80, 17 (Jordan).

78 Ramsden and Hamilton (n 4), 879-99.

79 ibid.

80 ibid; Rome Statute of the International Criminal Court (entered into force 1 July 2002) 2187 UNTS 90 (ICC Statute).

${ }_{81}$ EU, 'Policy Framework on Support to Transitional Justice' (2015) [http://eeas .europa.eu/archives/docs/top_stories/pdf/the_eus_policy_framework_on_support_to transitional_justice.pdf]; AU, 'Transitional Justice Policy' (2019) [https://au.int/sites/ $\overline{\mathrm{d}}$ fault/files/documents/36541-doc-au_tj_policy_eng_web.pdf]. 
formed in responding to atrocities. For instance, there is evidence that the work of the International Committee of the Red Cross (ICRC) and the UNHRC in international justice has influenced Assembly resolutions. ${ }^{82}$ Although impossible here to fully contextualise the influence of all these relevant actors on campaigns for accountability for atrocity crimes, it is nonetheless a broader context acknowledged and referenced in this book.

Still, there are some who might regard the role of the UNHRC in advancing international justice as being a more appropriate UN organ in which to focus scholarship. The UNHRC is the Assembly's creation; technically, its subsidiary organ. ${ }^{83}$ The Assembly also retains powers over its membership, being able to suspend a Member of the UNHRC 'that commits gross and systematic violations of human rights' ${ }^{84}$ Still, the UNHRC has been relatively autonomous in defining its agenda and, in many respects, has gone further than its parent organ in advancing international justice. To some Member States, the UNHRC would revitalise the Assembly's work. ${ }^{85}$ The UNHRC's mandate includes to 'address violations of human rights, including gross and systematic violations', making it relevant to the advancement of the norms of international justice. ${ }^{86}$ Like the Assembly, it has engaged in quasi-judicial activity in condemning conduct within States and establishing COIs to undertake investigations. ${ }^{87}$ The Assembly has established COIs, but the UNHRC has done so to a more significant extent in its short history, accounting for over 60 per cent of those established within the UN since $2006 .{ }^{88}$ The wide ranging coverage of these investigations (including Lebanon, Sudan and DPRK) might make up for accountability blind spots or oversights that have arisen in the principal political organs, including the Assembly. The UNHRC's creation of COIs has also been credited as having a catalytic effect within the UN, in supporting a referral by the Security Council of the Libya situation to the ICC Prosecutor. ${ }^{89}$

Does this mean that the UNHRC is better suited than the Assembly to advance international justice? Algeria argued that the UNHRC's Universal

\footnotetext{
82 Ramsden and Hamilton (n 4), 897-99.

83 UNGA Res 60/251 (2006), [1].

84 ibid, [8].

85 UNGA, 'Summary of the open-ended informal consultations held by the Commission on Human Rights pursuant to Economic and Social Council decision 2005/217' (21 June 2005) UN Doc A/59/847-E/2005/73, [27]-[28].

86 UNGA Res 60/251 (2006), [3].

87 Ramsden and Hamilton (n 4), 898.

88 Larissa van den Herik and Catherine Harwood, 'Commissions of Inquiry and the Charm of International Criminal Law' in Philip Alston and Sarah Knuckey, The Transformation of Human Rights Fact-Finding (OUP 2015), 236.

89 Compare UNHRC Res S-15/1 (2011) and UNSC Res 1970 (2011).
} 
Periodic Review, given that it fosters a spirit of cooperation, 'should be the primary tool for considering human rights issues' rather than the Assembly. ${ }^{90}$ However, it is erroneous to assume that the Assembly has been side-lined by its subsidiary organ. ${ }^{91}$ The Assembly has a rich history on international justice, dating to 1946; it has adopted wide-ranging resolutions in the field that continue to have impact, as this study shows. Furthermore, due to the wider membership and broader remit, a resolution by the Assembly carries greater persuasive weight than one by the UNHRC. ${ }^{22}$ Similarly, a specialism of the UNHRC has been to establish COIs; but the Assembly also has a practice in doing so, the IIIM-Syria a prominent example. ${ }^{93}$ Indeed, the IIIM-Syria model has been used by the UNHRC subsequently for Myanmar. ${ }^{94}$ Finally, the UNHRC is unable to produce resolutions having the same legal effects as ones by the Assembly in 'authorising' Member States to take action under the UN Charter or Uniting for Peace (see Chapter 7 of this volume). Furthermore, one of the UNHRC's functions is to 'make recommendations to the [Assembly] for the further development of international law in the field of human rights'. ${ }^{5}$ The UNHRC has also recognised the benefit of Assembly engagement in promoting enforcement action; the UNHRC implored the Assembly to recommend the Security Council to refer the Gaza situation to the ICC. ${ }^{96}$ The Assembly therefore remains centrally placed to advance international justice with the UNHRC, as its subsidiary organ, supporting these efforts.

While it is necessary to look at how Assembly activity might contribute - in tandem with other actors - towards the advancement of international justice, it must also be acknowledged that a major motivation of this book was to consider the ways in which the Assembly is able to overcome Security Council failures to take action in response to atrocities. Commentators have made casual references to a 'new Cold War' and a prediction that such tensions 'will affect nearly every important dimension of the international sys-

90 UNGA, Sixty-ninth session, 73rd plenary meeting (18 December 2014) UN Doc A/69/PV.73, 22.

91 See also UNGA, Sixty-sixth session, 89th plenary meeting (19 December 2011) UN Doc A/66/PV.89, 24 (Iceland) (Assembly 'enrich[es] the international human rights dialogue').

92 UNGA, Seventy-first session, 65th plenary meeting (19 December 2016) UN Doc A/71/PV.65, 34 (Ukraine).

93 UNGA Res 71/248 (2016).

94 UNHRC Res 39/2 (2018), [22] (welcomed in UNGA Res 73/264 (2018) preamble).

95 ibid, [5(c)].

96 UNHRC Res 16/32 (2011), [8]; UNHRC Res 39/2 (2018), [6] (inviting the Assembly to consider action on Myanmar). 
tem'.${ }^{97}$ Member States have often pointed to a Council legitimacy deficit and Assembly resolutions have been more pointed in condemning inaction by the permanent members. ${ }^{98}$ Members have called upon the Assembly to take more 'concerted action' to realise its 'responsibilities which should be exercised in regard to the maintenance of international peace and security' ${ }^{99}$ It has followed that the failure of the permanent members to reach accord, for instance, on a referral of the Syria situation to the ICC Prosecutor or the creation of an ad hoc tribunal for the Malaysia Airlines Flight 17 (MH17) disaster, has prompted reflection on creative solutions to Chapter VII deadlock. ${ }^{100}$ Reform proposals include a 'code of conduct' for voluntary veto abstention in 'mass atrocity' situations. ${ }^{101}$ Jennifer Trahan argued that there exists legal limits on the veto in atrocity situations grounded in the UN Charter and jus cogens nature of applicable norms. ${ }^{102}$ The feasibility of solutions outside of the Council has also been explored, including the Uniting for Peace mechanism. ${ }^{103}$ When exploring solutions outside the Council for accountability in the DPRK, the COI mused that States could use their 'combined sovereign powers ... to try perpetrators of crimes against humanity on the basis of the principle of universal jurisdiction', alluding to the Assembly as the forum for such delegation of powers to be established. ${ }^{104}$ This book considers these inter-organ dynamics on international justice and the scope for the Assembly to assume greater powers where the Council has failed.

Assembly practice is given special emphasis in this book. While the Charter language is a natural starting point in defining Assembly powers, there is also procedural latitude for them to develop these powers through practice.

97 Robert Legvold, 'Managing the New Cold War' (2014) Foreign Aff 74.

98 UNGA Res 66/253 B (2012). See also Martin Binder and Monika Heupel, 'The Legitimacy of the UN Security Council: Evidence from Recent General Assembly Debates' (2015) 59(2) Intl Studies Q 238.

99 Permanent Mission of Canada to the UN, 'Letter to the President of the Seventy-First Session of the UN General Assembly' (13 October 2016) [www.un .org/pga/71/wp-content/uploads/sites/40/2015/08/Informal-briefing-on-the-situation -of-Syria.pdf]. The Assembly has acknowledged the need to proactively address peace and security: UNGA Res 64/301 (2010), [4].

100 Jan Lemnitzer, 'International Commissions of Inquiry and the North Sea Incident: A Model for a MH17 Tribunal?' (2016) 27(4) EJIL 923.

101 UNSC, Sixty-eighth session, 7052nd meeting (29 October 2013), 13-14; Bolarinwa Adediran, 'Reforming the Security Council through a Code of Conduct: A Sisyphean Task?' (2018) 32(4) Ethics \& Intl Aff 463.

102 Trahan, 'Existing Legal Limits' (n 63).

103 Barber, 'Uniting for Peace not Aggression' (n 73); Yasmine Nahlawi, 'Overcoming Russian and Chinese Vetoes on Syria through Uniting for Peace' (2019) 24(1) JCSL 111; White, 'Relationship' (n 7), 293; Carswell (n 73); Zaum (n 76).

104 DPRK Report (n 67), [1201]. 
This reflects the interpretive principle that treaties are to be read in light of any subsequent practice or subsequent agreement establishing agreement of the parties regarding its interpretation (although, as Chapter 3 of this volume explains, 'established practice' based on 'general agreement' of the membership provides a better fit for UN Charter interpretation). ${ }^{105}$ Assembly practice, evidenced by the adoption of resolutions and the creation of subsidiary organs, establishes the scope of their existing powers. All relevant practice was surveyed, from the first session until, at the time of completion of this book, the most recent (1945-2021). Those resolutions and subsidiary organs identified to be concerned broadly with addressing atrocity situations and serious human rights violations were then catalogued and analysed according to the five major themes explored in this work (quasi-legislative; quasi-judicial; empowering; recommendatory; sanctioning). The language used in resolutions and explanations of vote were also carefully analysed given that they provide a window into ascertaining members' general agreement on Assembly powers.

Court judgments were another major source of material analysed in this book. The jurisprudence from international courts feature when appreciating the quasi-legislative and quasi-judicial effects of Assembly resolutions in the decision-making of other regimes (Chapters 2 and 4 of this volume). This focus recognises the important role of courts to the advancement of international justice, in rendering decisions that are capable of finding individuals or States responsible for atrocity crimes. How resolutions have influenced judicial outcomes is therefore a worthwhile study, even if broader conclusions cannot be made on the effect of resolutions on non-judicial actors (although correlates can sometimes be drawn based upon UN materials and secondary literature, as considered in this book). A wide range of courts relevant to international justice were surveyed. Those vested with the power to determine individual criminal responsibility included the ICC, International Criminal Tribunal for the former Yugoslavia (ICTY), International Criminal Tribunal for Rwanda (ICTR), Special Court for Sierra Leone (SCSL), Special Tribunal for Lebanon (STL) and the Extraordinary Chambers in the Courts of Cambodia (ECCC). The survey also covers the jurisprudence from regional human rights

105 Vienna Convention on the Law of Treaties (entered into force 27 January 1980) 1155 UNTS 331 (VCLT), art 31; Certain Expenses of the United Nations (Advisory Opinion) [1962] ICJ Rep 151, 175-79; Legal Consequences for States of the Continued Presence of South Africa in Namibia (Advisory Opinion) [1971] ICJ Rep 16, 22; Legal Consequences of the Construction of a Wall (Advisory Opinion) [2004] ICJ Rep 136, 149; ILC, 'Draft Conclusions on Subsequent Agreements and Subsequent Practice in Relation to the Interpretation of Treaties, with Commentaries' (2018) UN Doc A/73/10, 6; Julian Arato, 'Treaty Interpretation and Constitutional Transformation: Informal Change in International Organisations' (2013) 38 Yale J Intl L 289, 295. 
mechanisms - particularly the European Court of Human Rights (ECtHR) and Inter-American Court of Human Rights (IACtHR) - and their use of Assembly resolutions in the construction of norms on accountability for atrocity crimes in the context of human rights law. ${ }^{106}$

\section{STRUCTURE}

Including this Introduction, this book is divided into eight chapters. Chapter 2 analyses the quasi-legislative effect of Assembly resolutions in the judicial consideration of atrocity situations. Having set out the Assembly's broad quasi-legislative practice on international justice, Chapter 3 broadens the analysis to consider the relationship between resolutions and the development of international law, both institutionally (under the UN Charter) and externally (other treaties and customary international law). Chapter 4 then shifts focus onto the Assembly's quasi-judicial practice and how their resolutions have been used by institutional actors to support accountability responses to atrocity crimes. This is followed by Chapter 5, which evaluates the scope and effect of recommendations practice. The following two chapters consider the possibilities for the Assembly, in building upon some of its practice, to take creative solutions to advance international justice. Chapter 6 thus considers the Assembly's capacity to empower judicial or subsidiary organs to address atrocity situations, including to establish COIs, request ICJ advisory opinions and to create ad hoc criminal tribunals. Chapter 7 then rounds off the substantive analysis by looking into the legal feasibility of the Assembly assuming a function in coordinating and authorising lawful sanctions to advance accountability in atrocity situations. Chapter 8 concludes.

106 There is embryonic literature on 'international criminal law by other means': Alexandra Huneeus, 'International Criminal Law by Other Means: The Quasi-Criminal Jurisdiction of the Human Rights Courts' (2013) 107(1) AJIL 1. 